GATR Accounting and Finance Review

Journal homepage: www. gatrenterprise. com/GATRJournals/afr_issues. html

Acc. Fin. Review 5(3) 95 - 109 (2020)

\title{
CEO Compensation and Firm Performance in Emerging Market: Evidence from Indonesia Selected Listed Banks
}

\author{
Anwar Azazi \\ Department of Management, Faculty of Economics \& Business, Tanjungpura University, Pontianak, Indonesia.
}

\begin{abstract}
Objective - The objective of this study was to investigate empirically the relationship between the compensation of chief executive officers (CEO) and a firm's performance in the banking industry and to examine if CEO compensation affects bank performance differently between banks with and without prospect.

Methodology/Technique - The author uses two measures of performance, total return on assets and Tobin, s Q, and concentrate on total CEO compensation. All data are collected from annual reports of banks listed in Indonesia Stock Exchange for a sample of 23 commercial banks or 167 firm-year observation over the 2009-2018 period utilizing the purposive random sampling technique. CEO compensation and bank performance are then analysed employing pooled regression method.

Findings - This study finds supporting evidence for the agency-related problem in the banking industry in Indonesia. It then proves that high CEO compensation does have an inverse effect on bank performance, mainly on firm value. It also provides evidence that the pay-performance also demonstrates different patterns in firms with and without prospect.

Novelty - This study uses novel and hand-collected data on CEO compensation in the banking industry and developing econometric evidence regarding CEO pay-performance relating to banks with and without prospect.

Type of Paper: Empirical.

JEL Classification: G21, G32, M12.

Keywords: CEO compensation; Financial performance; Banking industry.

Reference to this paper should be made as follows: Azazi, A. (2020). CEO Compensation and Firm Performance in Emerging Market: Evidence from Indonesia Selected Listed Banks, Acc. Fin. Review, 5 (3): 95 - 109. https://doi.org/10.35609/afr.2020.5.3(2)
\end{abstract}

\section{Introduction}

The relationship between CEO compensation and firm performance has been widely investigated in many countries and has been one of the most widely studied questions in the corporate governance literature (Jensen \& Murphy, 1990; Bebchuck et.al., 2003) for more than two decades, particularly in the U.S. corporations.

\footnotetext{
* Paper info: Revised: September 16, 2020

Accepted: December 31, 2020

* Corresponding author: Anwar Azazi

E-mail: azazisedea@gmail.com

Affiliation: Department of Management, Faculty of Economics \& Business, Tanjungpura University,

Pontianak, Indonesia.
} 
In contrast, this topic is relatively ignored in emerging markets (Ghosh, 2006), but a few attempts have been made to study CEO compensation of Indonesian firms (Junarsin, 2011; Utary and Setyadi, 2014). A recent publication by Deloitte (2014) indicated that the remuneration of directors is increasingly one of the most hotly debated topics in the corporate governance arena. This is mainly due to the result of certain infamous recent examples of company collapses and the subsequent tension between directors and shareholders, with the latter demanding to understand and to be able to rationalise their directors' remuneration levels and methods of remuneration while, on the other hand, the directors wish their financial affairs to remain private. The theoretical literatures on agency theory and executive compensation reveal that CEO compensation should be aligned to firm performance (Jensen \& Murphy, 1990, Bebchuck et.al., 2003). In this framework, the principal (the shareholder) desires the agent (the manager) to maximise shareholder value but cannot accurately evaluate the executive's reaction function. The goals of the executives might be different from that of the shareholders (Reinatha and Komera, 2016). From this perspective, a manager may be more interested in defending personal power rather than pursuing profit maximising strategies (Bebchuk $\&$ Fried, 2003).

Unlike in the U.S., Indonesian firms have not been required to disclose information on compensation for any individual executives, and hence compensation data on individual executives of Indonesian corporations have not been available for researchers. The lack of such individual compensation data has been forcing researchers to tap into an alternative aggregate data source. As the mounting interest in corporate governance may impact on economic development, it is of considerable importance to study how firms compensate their top executives mainly in emerging markets, such Indonesia.

In addition, empirical findings on compensation-performance are inconclusive. Some studies find a positive relationship between CEO compensation and firm performance (Liling, 2006, Cheng \& Farber, 2008; Ozkan, 2011; Gao \& Li, 2015). Other studies conclude that CEO compensation has no impact on firm performance at all (Boyd, 1994). Finally, there are even some studies that find a negative relationship between CEO compensation and firm performance (Core, Holthausen \& Larcker,1999; Basu et al. ,2007). Therefore, whether CEO compensation has an impact on firm performance or not is an empirical issue. Most studies have been conducted in developed countries (e.g., Kato \& Kubo, 2006; Brunello, Graziano \& Parigi, 2001), while in the emerging markets this topic is relatively unexplored, particularly in the banking industry (Raithatha, and Komera, ,2016; Osei-Bonsu \& Lutta, 2016; Ghosh, 2006).

The contradictory empirical evidence in CEO pay-performance research is an important issue in emerging markets, especially in Indonesia. So, this study is an attempt to fulfil the literature gap on academic debate that exists on that subject. I select Indonesia as it reflects the characteristics of an emerging market economy, such as underdeveloped regulatory and institutional mechanisms, and weak investor activism (Ramdani and Witteloostuijn, 2009; Lin, Y.R and Fu X.M, 2017) as a developing managerial market (Ghosh, 2006). Research on CEO compensation in the banking industry in the emerging market is interesting due to its role in channelling funds from surplus party to deficit party to enhance the country's economic efficiency and to boost company's productivity. Our findings are expected to have applicability elsewhere in other emerging markets. In this respect, some questions are addressed concerning whether CEO compensation in banks affects firm performance and how CEO compensation affects bank performance differently between banks with and without prospect.

The purpose of this study is double. First, it provides empirical evidence on the relationship between the CEO compensation on firm performance in the banking industry. Second, it examines the sensitivity of payperformance within two different groups of banks: banks with prospect and those without prospect.

In addition, this study contributes to the literature in at least three ways. First, it employs a unique, handcollected initial pooled data set of 28 banks listed in BEI for the period 2009-2018. Second, studies focusing on the relation between CEO compensation and firm performance in banking industry in emerging market especially in Indonesia, where such a research is still limited. In this respect, this paper would possibly provide better insights on pay-performance in Indonesia. Third, the paucity of the relative performance 
evaluation in CEO compensation remains a puzzle (Murphy, 1999 as quoted by Raithatha and Komera, 2016) and is not well understood in the literature, this problem is salient in emerging markets like Indonesia which is characterized with weak corporate governance.

This paper is structured as follows: Following this introduction, the second section outlines the existing literature and hypothesis development. The third section discusses research methodology. The fourth section describes result and discussion. The fifth section provides the conclusion.

\section{Literature Review}

\subsection{The impact of executives' compensation on their performance}

Some theories have been advanced to explain the process in which managerial compensation is determined such as the agency theory and the tournament theory. However, agency theory has often been used in empirical studies (e.g., Doucouliagos et al. 2007; Gayle, Li and Miller, 2018; Elsayed N and Elbardan H.,2015). The relationship between executive compensation and firm performance has frequently been a key debate in corporate governance research (Core et al., 1999; Coles et al., 2012). Clearly, executive compensation and its determination are only one aspect of a wider governance framework. In the examination of pay-performance and performance-pay frameworks, it is important to control the effect of different corporate governance mechanisms in explaining the variability in such frameworks and practice.

\subsubsection{Agency theory}

According to agency theory, agency problems exist in any situation where one party entrusts responsibility of tasks to another party, owing to information asymmetry. Put in another term, agency theory emphasizes the contradictory motivations of executive directors (the agents), who are hypothesised to seek high rewards while minimising their effort, and the owners (the principals), whose ambition is to maximise their returns from ownership. Otten (2008) and Edmand et al. (2017) state that CEO compensation is regarded as a (partial) solution to deal with agency problems by incentive alignment and the transference of risks. CEO compensation is also used as an incentive mechanism to reduce agency problems which arise from the principal-agent problem as put forward by Jensen and Meckling (1976). In this context, a manager may be more interested in amassing and defending personal power rather than pursuing profit-maximizing strategies (Bebchuk \& Fried, 2003). The existing literature on agency theory suggests that one of the primary means for the shareholders to ensure that managers look after the best interest of shareholders is to tie managers' pay to the performance of their firms by means of providing high-powered incentives for managers to maximize the returns to shareholders. A stronger relationship between CEO compensation and performance furthermore also results in the selection and retention of more productive managers (Basu et al., 2007; Nanka-Bruce, 2011),.Since these factors are difficult to observe while selecting managers, providing top executives with performance related compensation can reduce the adverse selection problems (Arya \& Mittendorf, 2005).

Agency theory emphasises the contradictory motivations of executive directors (the agents), who are hypothesised to seek high rewards while minimising their effort, and the owners (the principals), whose ambition is to maximise their returns from ownership. It suggests the most direct association between compensation and performance, where better firm performance is expected to lead to higher executive compensation. This is supported theoretically by Jensen and Meckling (1976) and empirically by Jensen and Murphy (1990). 


\subsubsection{Tournament theory}

As the basis for an assessment of the impact of pay disparity on performance, tournament theory does not identify a specific association between compensation and performance, but it offers a general framework supporting the concept that paying high rewards to executive directors encourages performance at all levels within the firm (Bebchuck and Fried, 2003; Elsayed and Elbardan, 2015).

This tournament theory is empirically proven by Pissaris et al (2010) by assessing two questions: (1) whether pay disparity leads to incentives for managers to engage in strategies that benefit the shareholders of the firm and (2) whether governance quality moderates the pay disparity-performance relationship, consistent with agency theory. To answer these questions, Pissaris utilizes four measures of corporate governance to assess governance's moderating role on the relationship between pay disparity and firm performance. The results suggest that while pay disparity can provide incentives for better performance, which is consistent with tournament theory, however it can become destructive if it is reflective of agency conflict.

To sum up, agency theory explains a pay-performance framework, while the tournament approach is directly associated with the notion of performance-pay. Overall, the aforementioned theoretical perspectives are adopted to articulate the research hypotheses.

\subsection{Previous Empirical Findings}

Prior studies on CEO compensation-performance relationship become more complicated, as the number and the variety of variables included in the models increase such as the nature of the company, ownership structure, demographics on executives and directors, to name but a few. Until now researchers have not reached a consensus about the effects of compensation on CEOs' performance.

Ghosh (2006) studied the effect of corporate governance, firm performance, and corporate diversification on the board, as well as CEO compensation and its components in India. Using data for 462 firms in the Indian manufacturing industry over the 1997-2002 period, Ghosh finds that board compensation largely depends on current- and past-year firm performance only. He further explains that among the personal attributes of the CEO, only in-firm experience has significant effect on CEO compensation. This finding contradicts the existing studies, where current- and past-year firm performance, as well as age, experience, and education of the CEO are important factors in determining CEO compensation.

Luo and Jackson (2012) examine the relationship between executive compensation, ownership structure, and firm performance for Chinese financial corporations during 2001-2009. The results show that executive compensation in Chinese banks follows a relation-based rather than a market-based contract. However, there is little evidence in support of the pay-for-performance setting for Chinese executive compensation. Ownership concentration has significantly negative impacts while firm size has significantly positive effect on CEO compensation. Further, the involvement of state ownership tends to limit executive compensation, while the compensation committee is friendly and enhances management compensation. The results suggest that the government or regulation may ensure efficient corporate governance in business activity as a helping hand when corporate governance is weak.

Gregg et al. (2005) also find a weak link between CEO pay and firm performance. According to the authors, one possible explanation for these weak statistical results is that those researchers have relied on total cash pay (that is the sum of salary and annual bonus) as a measure of executive compensation. Thus, one can criticize those studies for their analysis excluding the equity-based component of compensation. Recently Ozkan (2007) finds that there is no significant relationship between firm performance and CEO compensation for a sample of large UK companies for the fiscal year 2003/2004. Although she includes both cash and equity-based components of CEO compensation in her analysis, one major limitation of her study is that her sample includes data for one year. Thus, evidence from these studies relating to firm performance and CEO compensation is mixed and hard to interpret. Wei (2000) studied 765 Japanese listed companies and found no remarkable positive correlation between business performance and executive incentives. 
Kubo and Saito (2008) estimated the sensitivity of Japanese presidents' wealth to shareholder wealth in the period 1977-2000. The authors showed that payment-performance sensitivity actually decreased substantially after 1990 due to bureaucracy. Ozkan (2007) furthermore examined UK non-financial firms and found that the institutional ownership is positively related to the pay-for-performance sensitivity of CEO compensation and negatively related to the level of CEO compensation. The result of Brik et al. (2008) was that the high pay performance sensitivity associates with low future returns, probably due to a reduction in firm risk. Doucouliagos et al. (2007) revealed an absence of a relationship between directors' payment and bank performance, and no association with prior year performance in the banking sector in Australia. However, they found a strong positive relationship between CEOs' remuneration and prior year bank performance. John and Qian (2003) conducted a comparative study between bank and manufacturing firms in the USA and they found that their pay-performance sensitivity in the banking industry, with its high leverage, is lower than it is in the manufacturing industry. They also documented that the pay-performance sensitivity of firms decreases with debt ratio and size. Beltratti et al. (2009) provided evidence that banks with more loans and more liquid assets performed better during the month following the Lehman bankruptcy, and so did banks from countries with stronger capital supervision and more restrictions on bank activities. Reithata and Komera (2016) examine the relationship between executive compensation and firm performance among Indian firms. The evidence suggests that firm performance measured by accounting, as well as market-based measures, significantly affects executive compensation. The authors also test for the presence of persistence in executive compensation by employing the system generalized methods of moments (GMM) estimator. They find significant persistence in executive compensation among the sample firms. Further, the authors report the absence of pay-performance relationship among the smaller sample firms and business group affiliated firms. Thus, their findings cast doubts over the performance-based executive compensation practices of Indian business group affiliated firms.

\subsection{Hypothesis Development}

\section{a. CEO Executive and firm performance}

Similar to Boyd (1994) and Ozkan (2007), but focusing on the banking sector in Australia, Doucouliagos et al. (2007) revealed an absence of a relationship between directors' payment and bank performance, and no association with prior year performance. Ghosh (2006) and Luo and Jackson (2012) found a weak link between CEO pay and firm performance. However, Core, Holthausen \& Larcker,1999; Basu et al. ,2007; Kubo and Saito (2008).) found a negative link between CEO pay and firm-performance. Conversely, Liling, 2006; Cheng \& Farber, 2008; Ozkan, 2011; Gao \& Li, 2015; Reithata and Komera, 2016) found a strong positive relationship between CEOs' remuneration and bank performance. The association between CEO compensation and firm performance should be positive, because CEO compensation is an incentive mechanism to reduce agency problems arising from the principal-agent problem.

H1: There should be a positive relationship between executive compensation and bank performance.

\section{b. Board Size and firm performance}

The board size influences its monitoring ability where the larger its size, the more capable it will be able to monitor top management. The board size represents the number of directors in position in the corporate board. John \& Senbet (1998) assert that the board of directors is basically viewed as the main corporate governance mechanism and the primary means for shareholders to indirectly oversee management activities (Al-Matar, Al-Swidi, and Fadzil , 2014). Along the same line, Jensen (1993) and Lipton and Lorsch (1992) as quoted by Junarsin (2011) also revealed that large boards are not as effective as smaller ones and there is a possibility that the members' discussions are not as meaningful as expected. Increase in board size corresponds to difficulties arising in coordination and processing of issues. Shaver (2005) mirrors the same 
statement by saying that a larger board primarily shows issues of responsibility diffusion leading to social loafing and urging the fractionalization of the group and the reduction of the members' commitment to strategic change. Moreover, larger boards are inefficient in terms of higher spending on the maintenance and report more difficulties in terms of planning, work coordination, decision making and having regular meetings because of the number of members. On the other hand, smaller boards are ideally able to avoid free riding by directors and encourage efficient decision-making process. Also, the bigger the board, the more possibility that the stakeholders' interests are considered and the less likely that decisions will be reached in favour of only a few members (Shao, 2010). According to Pfeffer and Salancik (1978), as cited by El-Matar et al, 2014, larger boards are more able to obtain invaluable resources including budgeting, funding and leveraging the external environments which can lead to the improvement of the performance of the firm. Ozkan (2011) finds that proportion of non-executive directors has a positive impact on CEO compensation suggesting that non-executive directors do not play a monitoring role. Following Ozkan (2011) and other previous researchers, I put forward the following hypothesis.

H2: There should be a positive relationship between board size and bank performance.

\section{c. Board Independence and firm performance}

Board composition has been highly debated in the realms of economics, organizational science literatures, and finance on the empirical and the theoretical levels. It has also been debated that effective ways of monitoring can assist the boards in making executives effectively take care of the shareholder's interests rather than their own (Ramdani \& Witteloostuijn, 2009). According to agency theory, a larger proportion of independent directors generally provide better firm performance because independent directors can minimize the agency cost as it makes the monitoring role and the strategic planning role of the board more effective. In general, it has been concluded by Ramdani and Witteloostuijn (2009) that the proportion of independent directors has an effect on firm performance. Composition of the board is also a measure of the quality of board characteristics that has caught the researchers and practitioners' attention. It is further argued that a board having more independent directors may minimize management opportunistic behaviour and in essence, safeguard the interests of shareholders more effectively as compared to their dependent counterparts (Zubaidah et al., 2009). On the basis of agency theory and resource dependence theory, the association between board independence and firm performance is considered to be positive. Several studies have generally reported a positive effect of board composition upon performance in developed countries like), (Cheng \& Farber, 2008; Ozkan, 2011; Nanka-Bruce, ,2011; Gao \& Li, 2015). Based on the theoretical perspective and debate above, the following hypothesis is expressed:

H3: There should be a positive relationship between non-executive/board independence and bank performance.

\section{d. Institutional Ownership and firm performance}

Ozkan (2007) examined UK non-financial firms and found that the institutional ownership is positively related to the pay-for-performance sensitivity of CEO compensation and negatively related to the level of CEO compensation. It is line with results obtained by Al Farooque et al. (2007) in listed firms in Bangladesh. Conversely, Lin, Y.R and Fu X.M (2017) found institutional ownership is positively related to firm performance, lending support to the "active monitoring" view stating that institutional investors actively monitor firms' business, minimize information asymmetry and agency problems, and enhance firm performance. Pirzada et al (2015) found similar a result in Malaysia.

H4: There should be a positive relationship between institutional ownership and bank performance.

e. Bank Efficiency and firm performance

Vardar (2013) investigates the link between the cost and profit efficiency scores of the banks in the Central and Eastern European Countries as well as Turkey along with their stock price performance to determine 
whether the efficiency scores are priced accordingly in bank stocks. Changes in efficiency scores of banks, obtained from Stochastic Frontier Analysis (SFA) model, are regressed against their stock price performance by applying fixed effects panel regression technique. Empirical results indicate that changes in profit efficiency estimates have a positive and significant impact on stock return. Arafat et al (2013) found a similar result, but the effect of bank efficiency and bank performance in Indonesia is weak.

H5: There should be a positive relationship between bank capital and bank performance.

\section{f. Bank Risk and firm performance}

Bank risk is measured by Non-performing Loan (NPL). Effective solutions on the NPL problem can boost the competitiveness of a banking system. Studies on bank failures e.g. Demirgüç-Kunt and Detragiache 1998, Barr and Siems 1994 (Webb, 2008; Doucouliagos, 2007; John and Qian, 2003) found that the asset quality is a significant predictor of insolvency, and that the failing banks always have high levels of NPL. This especially applies to investment and development banks, as the NPLs are not always the main (operational) problems faced by commercial banks Ozurumba (2016). In this light, NPLs is added to consider the potential risk usually in line with high profits. Ozurumba (2016) found a significant and negative effect of NPL toward firm performance in Nigeria and Arafat et al (2013) support this with a similar result in Indonesia.

H6: There should be a negative relationship between bank risk and bank performance.

\section{Research Methodology}

\subsection{Data and Research Procedures}

The data consisted of all the bank companies listed in the Indonesia Jakarta Stock Exchange (BEI) for the period 2007-2016, consisting of 40 banks. Annual data for main variables under investigation and all variables as employed to analyse the relationship between COE Compensation and Firm Performance. I hand-collected CEO Compensation data in the following steps. In the first step, I define the criteria for a listed bank that it must be having its financial data for at least 5 years during the period 2009-2018. Information on CEO Compensation was collected from the remuneration section of the firm's annual reports. Total compensation is used for his research consisting of annual compensation for both commissary board and CEO of each company. CEO compensation data include the Indonesian rupiah values of base salary, cash bonus, and long-term incentive plans. In the second step, I collect data on corporate governance variables such as board size, independent board, and institutional ownership. All data must be available for all variables under investigation. Finally, I obtained 23 banks that meet the criteria. Financial data are primarily from the annual report of each company and the Indonesia Capital Market Directory (ICMD) database. Sampling technique utilizes non-probability sampling that is purposive sampling technique (Sakaran, 2003). After removing outliers, the final sample accounts for 23 banks or 176 firm-year observation.

\subsection{Variables and Its Measurement}

I examine the relationship between pay and performance by considering consolidated executive compensation as the proxy for pay. I consider both accounting measures as well as market performance measures to represent firm performance. Following Cheng \& Farber (2008); Ozkan (2011), Nanka-Bruce (2011), Gao \& Li (2015) and Reithatha and Komera (2016), firm performance is proxied by Tobin's Q and by return on assets (ROA). Return on assets (ROA) is the accounting-based measures of firm performance, whilst Tobin's $Q$ representing firm value is market value of equity plus total liabilities divided by total assets are considered as the market-based measure of firm performance. Control variables include firm size, risk, capital, board size, board independence, and institutional ownership. 
In order to take size effect into account due to the different size of the banks, CEO compensation was standardized by Total assets (annual total CEO compensation/Total Assets). Firm Size is measured by natural logarithm of Total Assets. Risk is Non-performing loans/Total Loans (NPL), Bank Efficiency is measured by Operational Costs/Operational Revenue, Board Size is natural logarithm of total member of Board, Board Independence is non-executive director/total board member, while institutional ownership is percentage of stock held by institutional investor.

\subsection{Method of Analysis}

Executive compensation is influenced by the firm's contemporaneous performance. We empirically investigate the presence of contemporaneous relationship between executive compensation and firm performance employing the generic executive pay equation (Panel A). All models are estimated by using pooled ordinary least squares or POLS (Baltagi, 2008). In addition to the contemporaneous relationship, there might be a long-term relationship between executive compensation and firm performance as the compensation contracts may contain the elements of deferred pay. A strong case can be made that the current executive compensation is not only influenced by the firm's contemporaneous performance but also its past performance. Hence, I augment models in Panel A by including firms' lagged performance (RAO) as one of the independent variables (Panel B). Furthermore, to investigate if the relation between CEO compensation and firm performance is affected by growth opportunity of investment, I will split my sample into two groups: firms with growth opportunity and those without opportunity. Growth opportunity of investment is represented by Market-to-Book Ratio (MTBR). A firm is having growth opportunity if MTBR is more than 1 , otherwise.

In order to avoid causal relationship, I estimate the following dynamic model:

FP i,t $=\beta 0+\beta 1$ COMPi,t $+\beta 2$ ROAi,t-1 $+\beta 3$ SIZEi,t-1 $+\beta 4$ RISKi,t-t1 $+\beta 5$ BEFi,t- $1+\beta 6 \mathrm{BSi}, \mathrm{t}-1+\beta 7$ BIi,t$1+\beta 8$ IOi,t $-1+\varepsilon \mathrm{i}$

where PFi, : firm performance of bank $i$ at the period $t$. Firm performance is measured by Return on Asset (ROA) and Tobin's $Q$ representing firm value respectively.

The expected coefficient signs of regression: $\beta 1>0 ; \beta 2>0 ; \beta 3>0 ; \beta 4<0 ; \beta 5>0 ; \beta 6>0 ; \beta 7>0 ; \beta 8>0$

\section{Results and discussion}

\subsection{Descriptive Statistics}

The following table presents descriptive statistics of the variables under study. Average ROA of banking firms during the period 2009-2018 was 1,89 percent, whilst Tobin's Q reached 1.0413, implying that bank's performance indicates good prospect in the future.

Table 1. Descriptive Statistics of Variables

\begin{tabular}{|l|c|c|c|c|c|c|c|c|c|c|c|c|c|}
\hline & \multicolumn{4}{|l}{ Descriptive Statistics } & \multicolumn{3}{l|}{ Pearson's Correlation Matrix } \\
\hline & Min & Max & Mean & $\begin{array}{c}\text { Std. } \\
\text { Dev }\end{array}$ & ROA & $\begin{array}{c}\text { Tobin } \\
\text { Q }\end{array}$ & $\begin{array}{c}\text { CEO } \\
\text { Comp }\end{array}$ & $\begin{array}{c}\text { Firm } \\
\text { Size }\end{array}$ & $\begin{array}{c}\text { Risk } \\
\text { BE } \\
\text { F }\end{array}$ & BS & BI & IO \\
\hline ROA & -.076 & .1115 & .0189 & .020 & 1 & & & & & & & \\
\hline Tobin's Q & .527 & 2.189 & 1.041 & .2763 & -.031 & 1 & & & & & & & \\
\hline CEO Comp & .368 & .779 & .558 & .084 & -.010 & .065 & 1 & & & & & & \\
\hline Size & 14.908 & 22.971 & 18.554 & 1.956 & $.177^{*}$ & $-.201^{* *}$ & $-.650^{* *}$ & 1 & & & & \\
\hline Risk & .000 & .0882 & .0198 & .1575 & -.136 & .071 & $-.150^{*}$ & -.045 & 1 & & & & \\
\hline BEF & .215 & 3.916 & .769 & .624 & $-.152^{*}$ & .136 & .094 & $-.153^{*}$ & .124 & 1 & & & \\
\hline
\end{tabular}




\begin{tabular}{|l|c|c|c|c|c|c|c|c|c|c|c|c|c|}
\hline BS & 1.099 & 2.944 & 2.396 & .386 & $.231^{* *}$ & -.002 & $.319^{* *}$ & $.249^{* *}$ & $-.248^{* *}$ & -.116 & 1 & & \\
\hline BI & .000 & .667 & .2426 & .0949 & -.027 & .078 & -.024 & -.120 & .077 & -.132 & $-.422^{* *}$ & 1 & \\
\hline IO & .000 & .999 & .632 & .300 & -.089 & $.307^{* *}$ & $-.180^{* *}$ & $.242^{* *}$ & $.307^{* *}$ & .020 & $.167^{*}$ & -.074 & 1 \\
\hline
\end{tabular}

Note: $* *$ significance at level 1 percent, * significance at level 5 percent

Source: Own calculation, 2018

Average CEO Compensation was about 0.558 with small variation from its mean that is 0.084 . Financial variables such as firm size, Risk and Bank Efficiency BE) on average is 18.554, 0.0198 and 0.769 respectively. As for NPL, this figure is only about 1,8 percent, much lower than Bank Indonesia standard, 5 percent. It implies that Indonesian banking firms are shielded from the risk prospective. Bank efficiency also points out good performance because its ratio is lower than 94 percent as set by Bank Indonesia standard. High bank efficiency ratio is provided by low ratio. Board size, board independence and institutional ownership are all proxies for corporate governance variables. Board size is on average 2.40 with minimum size of 1.09 and maximum size reaches to 2.94. Average board independence is 24.26 percent, lower than BI standard of about 33 percent. Institutional ownership is relatively higher, amounting to 63.19 percent, implying that major investors in the banking firms in Indonesia are dominated by large corporations, financial institutions etc.

The correlation between Tobin's Q and CEO Compensation is negative but insignificant. Firm size, measured by Total Assets, corresponds negatively and significantly to profitability, Tobin's Q and CEO compensation. It means that he bigger the firms, the lower firm's performance and CEO compensation. Risk is having negative correlation with CEO compensation and it's marginally significant. It implies higher risk can have a pressure effect on CEO compensation in the banking industry. Furthermore, board size is associated positively and significantly with profitability, firm value and firm size, but it has inverse correlation with risk. The positive correlation between board size and profitability and firm value denotes that bigger board size is effectively influencing and disciplining the bank managers in running the business successfully. There exists a propensity of bigger firms to own bigger size of director.

With regards to institutional investors, they have a positive and significant correlation with firm value, firm size, risk, and board size. As for board size, Yermack (1996), by contrast, provides evidence that firm value and performance is a decreasing function of board size. The effectiveness of the institutional investors to oversee the CEO encourages the management in managing efficiently the corporation. The institutional investors have incentives to expand the asset of a firm. This can be explained by the fact that positive and significant correlation is found to exist between institutional investors and firm size. My result is not in line with that of Baysinger and Butler (1985) and Hermalin and Weisbach (Shaver, 2005; Shao, 2010). They find no meaningful relation between various characteristics of board composition and firm performance.

\subsection{CEO Compensation and Firm Performance}

The effect of CEO compensation on firm performance is provided by four models. In Panel A and B, there are two models consisting of model 1 with ROA as dependent variable, whist model 2 dependent variable is firm value which is proxied by Tobin's Q. Model 1 in Panel A, CEO compensation do not affect significantly on ROA. Neither do firm size, risk and bank efficiency.

Board size and board independence have positive impact and significance to profitability. Even board size impacted upon the firm profitability very significantly $(\alpha=1 \%)$. It means that large board size can play its role in overseeing the CEO, and larger boards in Indonesian banks are more able to obtain invaluable resources including budgeting, funding and leveraging the external environments which can lead to the improvement of the firm profitability as stated by Pfeffer and Salancik (1978), as cited by El-Matar et al, 2014). 
Board independence is also playing an important role as balancing power in board structure. It reflects furthermore the capability of non-executive directors in influencing the different interest of the parties in the board, mainly minority stockholders (Cheng \& Farber, 2008; Ozkan, 2011; Nanka-Bruce, ,2011; Gao \& Li, 2015).This is in line with agency theory where larger proportion of independent directors generally provide better firm performance because independent directors can minimize the agency cost as it makes the monitoring role and the strategic planning role of the board more effective (Ramdani D and Witteloostuijn,2009),. It also may minimize management opportunistic behaviour and in essence, safeguard the interests of shareholders more effectively as compared to their dependent counterparts (Zubaidah et al., 2009). Surprisingly, in model 1 (panel A) institutional investors influence negatively and significantly on firm profitability. This result corroborates that of Ozkan (2007) and Al Farooque et al. (2007), implies that the presence of institutional investors deteriorates the firm performance, measured by ROA. The effect of independent variables in model 1 is entirely able to affect firm performance with contribution reaching to 16.7 percent.

Panel 1 model 2 shows that CEO compensation is found to have negative and significant effect on firm performance, measured by Tobin's Q. This result bears out that obtained by Core, Holthausen \& Larcker,1999; Basu et al. ,2007; Kubo and Saito, 2008, and Brik et al., 2008). High CEO compensation results in depressing effect on firm performance due partly to market appreciating less with high compensation. There might be an indication that CEO in banking firms in Indonesia is overcompensated. Institutional ownership points out similar results to CEO compensation with respect to firm value. Negative and significant impact of institutional investors on firm value is surprisingly found out. The existence of this kind of investor has in effect no important role in influencing managerial decisions in the boards (Ozkan,2007; Al Farooque et al. ,2007). Board size and board structure have only marginal effect on firm performance (Tobin's Q).

Table 2. Effect of CEO Compensation on Firm Performance

\begin{tabular}{|l|c|c|c|c|}
\hline \multirow{2}{*}{} & \multicolumn{2}{|c|}{ Panel A } & \multicolumn{2}{c|}{ Panel B } \\
\cline { 2 - 5 } & Model 1 & Model 2 & Model 1 & Model 2 \\
\cline { 2 - 5 } & ROA & Tobin's Q & ROA & Tobin's Q \\
\hline Constant $)$ & $-.043(.026)$ & $1.864^{* * *}(.350)$ & $-.035(.024)$ & $1.920^{* * *}(.350)$ \\
\hline CEOCom & $-.014(.026)$ & $-.735^{* *}(.346)$ & $-.019(.024)$ & $-.756^{* * *}(.345)$ \\
\hline ROA t-1 & & & $.414^{* * *}(.066)$ & $1.903^{*}(.966)$ \\
\hline BS & $.019^{* * *}(.006)$ & $.135^{*}(.075)$ & $.015^{* * *}(.005$ & $.116(.076)$ \\
\hline BI & $.041^{* *}(.017)$ & $.416^{*}(.221)$ & $.044^{* * *}(.015)$ & $.436^{* *}(.221)$ \\
\hline IO & $-.011^{* *}(.005)$ & $.304^{* * *}(.062)$ & $-.009^{* *}(.004)$ & $.313^{* * *}(.062)$ \\
\hline Firm Size & $.001(.001)$ & $-.056^{* * *}(.014)$ & $.001(.001)$ & $-.059^{* * * *}(.014)$ \\
\hline Risk & $-.019(.066)$ & $-.985(.877)$ & $.015(.060)$ & $-.845(.878)$ \\
\hline BEF & $.000(.002)$ & $.047^{*}(.026)$ & $.001(.002)$ & $.053^{*}(.026)$ \\
\hline R 2 & .167 & .218 & .326 & .234 \\
\hline Adjusted $\mathrm{R}^{2}$ & .132 & .185 & .294 & .197 \\
\hline F Stat & 4.806 & 6.688 & 9.992 & 6.309 \\
\hline F Prob. & .000 & .000 & .000 & .000 \\
\hline D-W & 1.180 & .931 & 2.092 & .948 \\
\hline
\end{tabular}

Note: *** significance at level 1 percent, ** significance at level 5 percent, *significance at level 10 percent (figures in bracket is standard deviation)

Source: Own calculation, 2020

In Panel B model 1 another variable, profitability with time lag 1, was added. Similar to results in Panel A, CEO compensation does not affect firm profitability (ROA). One-time lag profitability is assumed to contribute to firm's current performance. Unsurprisingly, last year profitability is impacting positively and significantly on current profitability. This result supports Ghosh (2006). Board size and board independence are found to have positive and significant effect on firm profitability, as presented in model 1. Conversely, 
institutional investors (IO) has negative and significant effect of firm profitability. This result supports the result obtained by Ozkan (2007) and Al Farooque et al. (2007). Firm size, risk (NPL) and bank efficiency do not have any significant effect on firm profitability. This insignificant risk contradicts the result of Arafat et al (2013) which found that bank risk impacted negatively on the performance of the banking industry in Indonesia. Arafat et al (2013) also mentioned that the association of bank efficiency and bank performance in Indonesia is weak and this result is contradictory with that of Vardar (2013). This might be due to high proportion of operational expenses against operational income incurred in Indonesian banking firms.

Similar to result obtained in panel A model 2, CEO compensation in model 2 Panel B is found to impact negatively and significantly on Tobin's Q. This result is in line with that of Kubo and Saito (2008) in Japan but contradicts the result obtained by Buck, Liu, \& Skovoroda, (2008) in China. One-time lag profitability has only a marginal effect on firm value. Unsurprisingly, contradictory to result in Panel B model 1, board size is no more significant toward Tobin's Q. Meanwhile, board independence is showing the result which is consistent in all models. They are having a positive and significant influence on firm performance. This result is in line with that of Ramdani and Van (2009), and Kyereboah-Coleman \& Biekpe, 2006) found a positive association between the proportion of outside board members and performance. Firm size is also similar to and provides the result consistent for both model 2. This result corroborates that obtained by Kalsie and Shrivastav (2016) in India and Lehn et al. (2003). Lehn et al argued firm size and growth are important determinants of the size and structure of the boards. They found that firm size is directly related to the size and inversely proportional to the proxy for growth opportunities, that insider representation is inversely proportional to firm size and directly related to the proxy for opportunities growth and thus, a firm size has an effect on the firm's performance. Unfortunately, risk and bank efficiency do not have any impact on Tobin's Q.

\subsection{CEO Compensation and Firm Performance in Firms with and without prospect}

In order to confirm whether growth opportunity of investment matter to banking firm performance, this section provides results of the test by splitting firm samples into two categories. One is assumed to have growth opportunity of investment (good prospect), another is without growth opportunity of investment (bad prospect). Results of the test are presented in table 4.4.

\subsubsection{Firms with Growth Opportunity of Investment}

Panel A represents firms with good prospect as classified by MTB > 1. In model 1, for firms with good opportunity of investment in the future, CEO compensation does not have any significant effect on firm profitability. Conversely, one-time lag profitability, board size and board independence are all positive and significant to ROA. Positive one-time lag ROA implies that prior profitability is an important factor in influencing the future profitability. This result is in line with that of Ghosh (2006) in India.

Board size is also playing an important role in impacting ROA in those firms. If the board members anticipate that the future prospect of the firm is favourable, they are motivated to encourage CEO to work harder to exploit this good prospect by enhancing the productivity and efficiency of the firm in order to gain high profit Pfeffer and Salancik (1978), as cited by El-Matar et al, 2014). Moreover, board independence proves to be effective in playing its role on the board. As balancing power, they are able to influence the strategic decision of the CEO of banking firms. Consistent to previous results, institutional investors affect negatively on ROA, whereas firm size, risk and bank efficiency do not any impact on ROA. This is in line with the results of (Cheng \& Farber, 2008; Ozkan, 2011; Nanka-Bruce, ,2011; Gao \& Li, 2015. Zubaidah et al. (2009) argues that larger board independence may minimize management opportunistic behaviour and in essence, safeguards the interests of shareholders more effectively as compared to their dependent counterparts 
For model 2 in Panel A, CEO compensation has a negative and marginally significant effect on Tobin's Q, whilst one-time lag ROA provides contradictive results compared with model 1. This result supports that of Core, Holthausen \& Larcker,1999; Basu et al. ,2007; Kubo and Saito, 2008) who found a negative link between CEO pay-performance. Board size in model 2, however, turns out to be insignificant in relation to Tobin's Q. Board independence brings about positive and significant impact on Tobin's Q and is positive for institutional investors (Lin, Y.R and Fu X.M (2017) and Firzada (2015).

Table 3. CEO Compensation and Firm Performance: Does Growth Opportunity of Investment Matter?

\begin{tabular}{|c|c|c|c|c|}
\hline & \multicolumn{2}{|l|}{ Panel A } & \multicolumn{2}{|l|}{ Panel B } \\
\hline & $\begin{array}{l}\text { Model } 1 \\
\text { (ROA) }\end{array}$ & $\begin{array}{l}\text { Model } 2 \\
\text { (Tobin's Q) }\end{array}$ & $\begin{array}{l}\text { Model } 1 \\
\text { (ROA) }\end{array}$ & $\begin{array}{l}\text { Model } 2 \\
\text { (Tobin's Q) }\end{array}$ \\
\hline & \multicolumn{2}{|c|}{ MTB>1 } & \multicolumn{2}{|c|}{ MTB $<1$} \\
\hline (Constant) & $-.066 * *(.028)$ & $2.005 * * *(.479)$ & $.016(.046)$ & $1.413 * *(.610)$ \\
\hline CEOCom & $-.002(.026)$ & $-.860 *(.444)$ & $-.027(.044)$ & $-.447(.583)$ \\
\hline ROA t-1 & $.537 * * *(.079)$ & $1.488(1.374)$ & $.158(.112)$ & $2.334(1.490)$ \\
\hline BS & $.021 * * *(.006)$ & $.026(.101)$ & $.006(.010)$ & $.220 *(.128)$ \\
\hline BI & $.053^{* * *}(.015)$ & $.551 * *(.256)$ & $.025(.031)$ & $.325(.414)$ \\
\hline IO & $-.014 * *(.006)$ & $.386 * * *(.112)$ & $-.002(.007)$ & $.362 * * *(.091)$ \\
\hline Firm Size & $.001(.001)$ & $-.053 * * *(.018)$ & $.000(.002)$ & $-.049 * *(.023)$ \\
\hline Risk & $.074(.112)$ & $-2.297(1.938)$ & $.007(.082)$ & $-.731(1.092)$ \\
\hline BEF & $.002(.002)$ & $.080 * *(.033)$ & $.001(.003)$ & $-.002(.043)$ \\
\hline R2 & .621 & .255 & 0.040 & .312 \\
\hline Adjusted R2 & .587 & .189 & -.070 & .234 \\
\hline F Stat & 18.398 & 3.849 & .361 & 3.975 \\
\hline F Prob. & .000 & .001 & -937 & .001 \\
\hline $\mathrm{D}-\mathrm{W}$ & 2.073 & 1.750 & 1.969 & 1.597 \\
\hline
\end{tabular}

Note: *** significance at level 1 percent, $* *$ significance at level 5 percent, *significance at level 10 percent (figures in bracket is standard deviation)

Source: Own calculation, 2020

\subsubsection{Firms without Growth Opportunity of Investment}

Panel B provides results of statistical test for firms without growth opportunity of investment. In Model 1, no coefficients do affect significantly on firm performance, measured by ROA. One-year time lag profitability, board size, and board independence still have positive sign as theory predicted (Gosh, 2006). Model 2 shows that CEO compensation, even though still have negative sign as the theory predicted, it is not significant. Board size is only marginally significant. This is contradictory in banks with prospect. Board independence, however, is not significant. Institutional investors are found to be insignificant on both ROA and Tobin's Q, contradictory with banks with prospect. Firm size impacted negatively and significantly firm performance as theory implies, but not significant. In addition, risk and bank efficiency do not have any impact on Tobin's Q.

To summarise, there are significant differences of factors which affect bank performance between banks with and those without prospect. Banks with prospect performed better, whilst those without prospect and higher CEO compensation in banks performed worst. This result may indicate that CEO in banking firms in Indonesia are likely overcompensated. 


\section{Conclusion and recommendation}

Effect of CEO compensation differs on firm performance among various econometric models. CEO compensation is only impacting negatively and significantly on Tobin's $\mathrm{Q}$ for banking firms with prospect, but no coefficients of CEO compensation are significantly associated with ROA. This result suggests that firms with weaker governance structures have greater agency problems; that CEOs at firms with greater agency problems receive greater compensation; and that firms with greater agency problems perform worse. On the one hand, firms with good prospect, time lag one-period profitability (ROA), Board size and board composition are having positive signs, as theory predicted, and significant on firm performance, measured by ROA. While Institutional ownership affects negatively and significantly on ROA. Firm size, risk and bank efficiency are not found to affect significantly. On the other hand, for firms with good prospect, when firm performance is measured by Tobin's Q, CEO compensation is marginally having significant and negative effect on firm performance. Board composition, institutional ownership and bank efficiency affect positively and significantly on Tobin's Q. Firms size however is negatively and significantly associated with Tobin's Q. Other variables are not significant. There is a probability that CEO pay is overcompensated.

Managerial implication presented in this paper is a first step in the direction of understanding the pay to performance relation in the banking industry with different setting in Indonesia. From corporate governance perspective, it is also important in designing CEO compensation, because the bank's managers appear to be over compensated. To deal with this problem, incentive-based contracts might be are effective, due to the positive pay-to-performance link, when controlling for simultaneity as Liling (2006) suggests. Furthermore, additional research is warranted, which should extend both the time series and the cross-section aspects of the data. Total CEO compensation as used in this study should be broken down, for instance, separating it into commissionaire payment and director member compensation. Splitting bank samples into private and state banks, analyzing the impact of managerial compensation in relation to bank risk ( $\mathrm{z}$-score), extending the performance measure such as market value, and the role of competition among banks are factors that should be taken into consideration to gain the more specific picture of CEO compensation in relation to bank riskiness and financial performance in banking industry.

\section{References}

Al Farooque, O., Van Zijl, T., Dunstan, K., \& Karim, A. W. (2007). Corporate governance in Bangladesh: Link between ownership and financial performance. Corporate governance: An international review, 15(6), 1453-1468. https://doi.org/10.1111/j.1467-8683.2007.00657.x

Al-Matari, E. M., Al-Swidi, A. K., \& Fadzil, F. H. (2014). The effect of board of directors' characteristics, audit committee characteristics and executive committee characteristics on firm performance in Oman: An empirical study. Asian Social Science, 10(11), 149-171. http://doi.org/10.5539/ass.v10n11p149

Arafat, M. Y., Warokka, A., Buchdadi, A. D., \& Suherman. (2013). Banking efficiency and performance: a test of banking characteristics in an emerging market. Journal for Global Business Advancement, 6(1), 13-23. https://doi.org/10.1504/JGBA.2013.053475

J. Global Business Advancement, Vol. 6, No. 1, p.13-23

Arya, A., \& Mittendorf, B. (2005). Offering stock options to gauge managerial talent. Journal of Accounting and Economics, 40(1-3), 189-210. https://doi.org/10.1016/j.jacceco.2005.02.001

Baltagi, B. (2008). Econometric analysis of panel data. John Wiley \& Sons.

Basu, S., Hwang, L. S., Mitsudome, T., \& Weintrop, J. (2007). Corporate governance, top executive compensation and firm performance in Japan. Pacific-Basin Finance Journal, 15(1), 56-79. https://doi.org/10.1016/j.pacfin.2006.05.002

Bebchuk, L. A., \& Fried, J. M. (2003). Executive compensation as an agency problem. Journal of economic perspectives, 17(3), 71-92. DOI: 10.1257/089533003769204362

Bebchuk, Lucian Arye; Fried, Jesse M. (2003) "Executive Compensation as an Agency Problem," National Bureau of Economic Research Working Paper Series, No. 9813. Cambridge, Massachusetts, July. 
Beltratti, A., \& Stulz, R. M. (2009). Why did some banks perform better during the credit crisis? A cross-country study of the impact of governance and regulation (No. w15180). National Bureau of Economic Research. DOI $10.3386 / w 15180$

Boyd, B. K. (1994). Board control and CEO compensation. Strategic management journal, 15(5), 335-344. https://doi.org/10.1002/smj.4250150502

Brunello, G., Graziano, C., \& Parigi, B. (2001). Executive compensation and firm performance in Italy. International Journal of Industrial Organization, 19(1-2), 133-161. https://doi.org/10.1016/S0167-7187(99)00026-0

Brick, I. E., Palmon, O., \& Wald, J. K. (2012). Too much pay-performance sensitivity? Review of Economics and Statistics, 94(1), 287-303. https://doi.org/10.1162/REST_a_00142

Buck, T., Liu, X., \& Skovoroda, R. (2008). Top executive pays and firm performance in China. Journal of International Business Studies, 39(5), 833-850. https://doi.org/10.1057/palgrave.jibs.8400386

Cheng, Q., \& Farber, D. B. (2008). Earnings restatements, changes in CEO compensation, and firm performance. The Accounting Review, 83(5), 1217-1250. https://doi.org/10.2308/accr.2008.83.5.1217

Coles, J., Lemmon, M. and Meschke, F. (2012, January), "Structural Models and Endogeneity in Corporate Finance: The Link between Managerial Ownership and Corporate Performance", Journal of Financial Economics, 103(1), 149168.

Core, J. E., Holthausen, R. W., \& Larcker, D. F. (1999). Corporate governance, chief executive officer compensation, and firm performance. Journal of financial economics, 51(3), 371-406. https://doi.org/10.1016/S0304-405X(98)00058-0 Deloitte (2014), Disclosure of remuneration: a hot topic' Available at: http://www2.deloitte.com/content/dam/Deloitte/za/Documents/governance-risk compliance/ZA_Disclosure of Remuneration A Hot Topic_04042014.pdf [Accessed 4 November 2015].

Doucouliagos, H., Haman, J., \& Askary, S. (2007). Directors' remuneration and performance in Australian banking. Corporate governance: an international review, 15(6), 1363-1383. https://doi.org/10.1111/j.1467-8683.2007.00651.x

Edmans, A., Gabaix, X., \& Jenter, D. (2017). Executive compensation: A survey of theory and evidence. In The handbook of the economics of corporate governance (Vol. 1, pp. 383-539). North-Holland. https://doi.org/10.1016/bs.hecg.2017.11.010

Elsayed, N., \& Elbardan, H. (2018). Investigating the associations between executive compensation and firm performance. Journal of Applied Accounting Research. https://doi.org/10.1108/JAAR-03-2015-0027

Firth, M., Fung, P. M., \& Rui, O. M. (2007). How ownership and corporate governance influence chief executive pay in China's listed firms. Journal of Business Research, 60(7), 776-785. https://doi.org/10.1016/j.jbusres.2007.01.014

Gao, H., \& Li, K. (2015). A comparison of CEO pay-performance sensitivity in privately-held and public firms. Journal of Corporate Finance, 35, 370-388. https://doi.org/10.1016/j.jcorpfin.2015.10.005

Gayle, G. L., Li, C., \& Miller, R. A. (2018). How Well Does Agency Theory Explain Executive Compensation? https://doi.org/10.20955/r.2018.201-36

Ghosh, A. (2006). Determination of executive compensation in an emerging economy. Evidence from India. Emerging Markets Finance and Trade, 42(3), 66-90. https://doi.org/10.2753/REE1540-496X420304

Gregg, P., Jewell, S., \& Tonks, I. (2005). Executive Pay and Performance in the UK 1994-2002.

Jensen, M. C., \& Murphy, K. J. (1990). Performance pay and top-management incentives. Journal of political economy, 98(2), 225-264.

John, K., \& Qian, Y. (2003). Incentive features in CEO compensation in the banking industry. Economic Policy Review, 9(1).

Junarsin, E. (2011). Executive compensation and firm performance: An empirical examination. European Journal of Economics, Finance and Administrative Sciences, 28, 163-179.

Kato, T., \& Kubo, K. (2006). CEO compensation and firm performance in Japan: Evidence from new panel data on individual CEO pay. Journal of the Japanese and International Economies, 20(1), 1-19. https://doi.org/10.1016/j.jjie.2004.05.003

Kubo, K., \& Saito, T. (2008). The relationship between financial incentives for company presidents and firm performance in Japan. The Japanese Economic Review, 59(4), 401-418. https://doi.org/10.1111/j.14685876.2008.00420.x

Lilling, M. S. (2006). The link between CEO compensation and firm performance: Does simultaneity matter? Atlantic Economic Journal, 34(1), 101-114. https://doi.org/10.1007/s11293-006-6132-8

Lin, Y. R., \& Fu, X. M. (2017). Does institutional ownership influence firm performance? Evidence from China. International Review of Economics \& Finance, 49, 17-57. https://doi.org/10.1016/j.iref.2017.01.021 
Luo, Y., \& Jackson, D. (2012). Executive compensation, ownership structure and firm performance in Chinese financial corporations. Global Business and Finance Review, 17(1), 56-74. http://dx.doi.org/10.2139/ssrn.1893554

Nanka-Bruce, D. (2011). Corporate governance mechanisms and firm efficiency. International Journal of Business and Management, 6(5), 28. doi:10.5539/ijbm.v6n5p28

Osei-Bonsu, N., \& Lutta, J. G. M. (2016). CEO cash compensation and firm performance: An empirical study from emerging markets. Business and Economic Research, 6(2), 79-99. doi:10.5296/ber.v6i2.9805

Otten, J (2008), Theories on executive pay A literature overview and critical assessment, Online at http://mpra.ub.unimuenchen.de. Download Ocbober 20,2018

Ozurumba, B. A. (2016). Impact of non-performing loans on the performance of selected commercial banks in Nigeria. Research journal of Finance and Accounting, 7(16), 95-109.

Ozkan, N. (2007). CEO pay-for-performance sensitivity and corporate governance: an empirical investigation of UK panel data. European Financial Management, 17(2), 260-285.

Ozkan, N. (2011). CEO compensation and firm performance: An empirical investigation of UK panel data. European Financial Management, 17(2), 260-285.

Otten, J. (2007). Theories on executive pay: A literature overview and critical assessment. Available at SSRN 1088272. http://dx.doi.org/10.2139/ssrn.1088272

Pirzada, K., Mustapha, M. Z. B., \& Wickramasinghe, D. (2015). Firm Performance, Institutional Ownership and Capital Structure: A Case of Malaysia. Procedia-Social and Behavioral Sciences, 211, 170-176. https://doi.org/10.1016/j.sbspro.2015.11.025

Pissaris, S., Jeffus, W., \& Gleason, K. C. (2010). The joint impact of executive pay disparity and corporate governance on corporate performance. Journal of Managerial Issues, 306-329.

Raithatha, M., \& Komera, S. (2016). Executive compensation and firm performance: Evidence from Indian firms. IIMB Management Review, 28(3), 160-169. https://doi.org/10.1016/j.iimb.2016.07.002

Ramdani D and Witteloostuijn A. V (2009) Board independence, CEO duality and firm performance: A quantile regression analysis for Indonesia, Malaysia, South Korea and Thailand, Working Papers from University of Antwerp, Faculty of Applied Economics, download: https://repository.uantwerpen.be/docman/irua/62cede/f52924f7.pdf (application/pdf)

Shao, G. (2010). The effects of board structure on media companies' performance: A stakeholder perspective. Journal of Media Business Studies, 7(3), 1-16. https://doi.org/10.1080/16522354.2010.11073508

Shaver, D. (2005). Characteristics of corporate boards in single-industry and conglomerate media companies. International Journal on Media Management, 7(3-4), 112-120.

Utary, A. R., Setyadi, D., \& Indonesia, S. (2014). An Empirical Analysis of Relationships between Capital Structure, Market Power, Profitability and Expenditure. structure, 6(36).

Vardar, G. (2013). Efficiency and Stock Performance of Banks in Transition Countries: Is There A Relationship? International Journal of Economics and Financial Issues, 3(2), 355.

Webb, E. (2008). Regulator scrutiny and bank CEO incentives. Journal of Financial Services Research, 33(1), 5-20.

Wei, G. (2000). Advanced Executive Incentive and the Listed Firm Performance. Chinese Journal of Economic Research, 3, 32-39.

Yermack, D. (1996). Higher market valuation of companies with a small board of directors. Journal of financial economics, 40(2), 185-211.

Abidin, Z. Z., Kamal, N. M., \& Jusoff, K. (2009). Board structure and corporate performance in Malaysia. International journal of economics and finance, 1(1), 150-164. 